Journal of Animal and Veterinary Advances 9 (17): 2256-2260, 2010

ISSN: $1680-5593$

(C) Medwell Journals, 2010

\title{
In situ Ruminal Degradation and in vitro Gas Production of Chemically Treated Sesame Stover
}

\author{
M. Danesh Mesgaran, M. Malakkhahi, A.R. Heravi Moussavi, A. Vakili and A. Tahmasbi \\ Excellence Center for Animal Science, Department of Animal Science, Faculty of Agriculture, \\ Ferdowsi University of Mashhad, P.O. Box 91775-1163, Mashhad, Iran
}

\begin{abstract}
This study was conducted to determine the effect of chemical treatment on fermentative activity and nutritive value of Sesame stover by in situ and in vitro gas production techniques. Treatments were untreated Sesame Stover (SS), SS+Sulphuric Acid (SSA), SS+Urea (SSU), SS+NaOH (SSN) and SS+Urea+NaOH (SSUN). Nylon bags $(9 \times 17 \mathrm{~cm})$ each containing $5 \mathrm{~g}$ sample $(2 \mathrm{~mm}$ screen) were incubated in the rumen of fistulated sheep for $0.0,4,8,16,24,36,48,72$ and $96 \mathrm{~h}$ to determine the ruminal disappearance. Cumulatve gas production was recorded at $2,4,6,8,12,24,36,48,72$ and $96 \mathrm{~h}$ of incubation and the equation of $\mathrm{P}=\mathrm{A}\left(1-\mathrm{e}^{-\mathrm{ct}}\right)$ was used to describe the kinetics of gas production. Results showed that NDF concentration of the samples was significantly $(\mathrm{p}<0.05)$ decreased by sulphuric acid treatment also the urea caused a significant $(\mathrm{p}<0.05)$ increase in $\mathrm{CP}$ content of sesame stover. Dry matter ruminal disappearance was significantly $(\mathrm{p}<0.05)$ increased by $\mathrm{NaOH}$ treatment. Moreover, the in situ quickly degradable fraction of $\mathrm{CP}$ was increased $(0.625 \pm 024)$ when urea applied. The $\mathrm{b}$ fraction and rate of gas production were significantly $(\mathrm{p}<0.05)$ increased $(72.32 \pm 2.88)$ and decreased $(0.029 \pm 0.002)$, respectively by adding the $\mathrm{NaOH}$ to SS.
\end{abstract}

Key words: Sesame stover, chemical treatment, in vitro gas production, in situ, seed oil, Iran

\section{INTRODUCTION}

Sesame (Sesame indicun L.) is an annual plant, broadleaf that cultivated after wheat in arid and semi-arid regions of Iran for its seed oil and extensively used for medicinal and food purposes. Sesame stover is the most abundance residual of Sesame cultivation in Iran and traditionally used as a basal feed in ruminants (Mesgaran et al., 2009). A number of studies (Weixian et al., 1995) have also proven that crop residues are low in available nutrients taking longer lag time and slow in rate of microbial fermentation. These characteristics of straw limit its intake and digestibility; thereby hamper the productivity of farm animals.

Treatment of straw with chemicals like ammonia and ammonia precursors as urea to increase the digestibility is used in many parts of the world. Such treatments generally increase both the rate and extent of fiber digestion in the rumen which leads to higher energy value of the treated material as well as to a higher intake (Celik et al., 2003). There are a number of chemical reactions taking placed during alkali treatment. Saponification of ester linkages between acetic acid and phenolic acids, polysaccharides and/or lignin as well as such linkages between uronic acid residues of xylan in hemicelluloses and lignin would be expected (Ribeiro, 1991; Chaudhry, 1998) reported significant increase of in vitro dry matter digestibility of wheat straw when it was treated with sodium hydroxide. The processing of fibrous feed with urea leads to the production of ammonia which caused an increase in the rumen microbiota accessing to the cell wall polysaccharides as well as favoring the degradative action of the bacterial and fungal enzymes in the rumen (Horn et al., 1989). In addition, urea increases the nutritional value of fibrous materials by making more digestible cellulose and hemicellulose available (Silva and Qrskov, 1988). This creates favorable condition in the rumen for the development of the cellulytic bacteria which degrade the plant cell wall (Silva and Qrskov, 1988). The aims of the present study were to evaluate the effect of chemical treatment of sesame stover with $\mathrm{NaOH}$ and urea or sulphuric acid on chemical composition, in vitro gas production and in situ ruminal degradation parameters of Dry Mater (DM) and Crude Protein (CP).

\section{MATERIALS AND METHODS}

Experimental samples and chemical analysis: Sesame Stover (SS) was obtained from the Iranian plant varieties adapted to grow in semi-arid condition. The samples were

Corresponding Author: M. Danesh Mesgaran, Excellence Center for Animal Science, Department of Animal Science, Faculty of Agriculture, Ferdowsi University of Mashhad, P.O. Box 91775-1163, Mashhad, Iran 
manually chopped ( $5 \mathrm{~cm}$ length) and used as untreated or treated with sulphuric acid (SSA, $2 \mathrm{~mL} / 100 \mathrm{~g} \mathrm{DM}$ ), urea (SSU, $3 \mathrm{~g} / 100 \mathrm{~g} \mathrm{DM}$ ), $\mathrm{NaOH}$ (SSN, $4 \mathrm{~g} / 100 \mathrm{~g} \mathrm{DM}$ ) or both $\mathrm{NaOH}$ and urea [SSUN, $\mathrm{NaOH}$ as $4 \mathrm{~g} / 100 \mathrm{~g}$ DM was sprayed on the stover and kept for $48 \mathrm{~h}$ then urea $(3 \mathrm{~g} / 100 \mathrm{~g}$ of initial DM) was added]. Treated SS were ensiled under un-aerobic condition for 4 weeks. Feed samples were dried at $60^{\circ} \mathrm{C}$ in oven dryer for $48 \mathrm{~h}$ and then ground to pass through a $2 \mathrm{~mm}$ screen. Samples were analyzed for Crude Protein (CP) (Kjeltec 2300 Auto analyzer, Foss Tecator AB, Hoganas, Sweden), Organic Matter (OM) and ash. Neutral Detergent Fiber (NDF) and Acid Detergent Fiber (ADF) were determined using the method of Van Soest et al. (1991).

Ruminal degradability: In situ degradation of DM and CP was studied following the nylon bag technique described by Mehrez and Orskov (1977). About 4 sheep (49.6 $\pm 2 \mathrm{~kg}$ ) fitted with ruminal fistulae were used. The animals were fed with $1.5 \mathrm{~kg}$ DM alfalfa hay and $0.4 \mathrm{~kg}$ DM concentrates (165 g CP kg-1 DM) per head per day at 8.00 and 17:00 h. Approximately, $5 \mathrm{~g} \mathrm{DM}$ of each sample (10 bags per each feed) was placed in a polyester bag $(9 \times 17 \mathrm{~cm}$; pore size of $52 \mu \mathrm{m})$ and incubated in the rumen for 0.0 (bags were washed with cold tap water) $2,4,8,16$, $24,36,48,72$ and $96 \mathrm{~h}$. After removal from the rumen, bags were washed with tap water and subsequently dried using oven dryer $\left(60^{\circ} \mathrm{C}, 48 \mathrm{~h}\right)$ then weighed to determine DM disappearance. Crude protein concentration of unincubated and rumen incubated samples were then determined.

In vitro gas production: In vitro gas production was determined according to Menke and Steingass (1988) procedures. Rumen content was collected from 4 sheep $(49.6 \pm 2 \mathrm{~kg}$ ) fitted with ruminal fistulae. The animals were fed with $1.5 \mathrm{~kg}$ DM alfalfa hay and $0.4 \mathrm{~kg}$ DM concentrate ( $165 \mathrm{~g} \mathrm{CP} \mathrm{kg}^{-1} \mathrm{DM}$ ) per head per day at 8.00 and $17.00 \mathrm{~h}$. Rumen content was strained through 4 layers of cheesecloth. The laboratory handling of rumen liquor was carried out under a continuous flow of $\mathrm{CO}_{2}$. About $200 \mathrm{mg}$ of each sample was measured into each syringe (4 replicates per each sample). Then, it was filled with $30 \mathrm{~mL}$ of medium consisting of $10 \mathrm{~mL}$ of rumen fluid and $20 \mathrm{~mL}$ of buffer solution as described by Menke and Steingass (1988). Four blank syringes were also provided. The syringes were placed in an incubator $\left(38.6^{\circ} \mathrm{C}\right)$. Gas production was recorded after $2,4,8,12,16,24,36,48,72$ and $96 \mathrm{~h}$. of incubation. Total gas values of the incubated samples were corrected for blank incubation.

Calculations and statistical analysis: The data from in situ studies were fitted into an exponential model $\left\{\mathrm{p}=\mathrm{a}+\mathrm{b}\left(1-\mathrm{e}^{-\mathrm{ct}}\right)\right\}$ of Orskov et al. (1980) by using the Maximum Likelihood Programme to obtain estimates of a, $\mathrm{b}$ and $\mathrm{c}$ for each sample in each sheep. Here, a is quickly degradable fraction, $\mathrm{b}$ is slowly degradable fraction, $\mathrm{c}$ is constant fractional degradation rate and $t$ is the hours of incubation.

Gas production in each syringe was measured directly at $2,4,8,12,16,24,36,48,72$ and $96 \mathrm{~h}$. Cumulative gas production data were fitted to the exponential equation:

$$
\mathrm{Y}=\mathrm{a}+\mathrm{b}\left(1-\mathrm{e}^{-\mathrm{ct}}\right)
$$

Where:

$\mathrm{b}=$ The gas production from the fermentable fraction $(\mathrm{mL})$

$\mathrm{c}=$ The gas production rate constant $\left(\mathrm{mL} \mathrm{h}^{-1}\right)$

$\mathrm{t}=$ The incubation time $(\mathrm{h})$

$\mathrm{y}=$ The gas production at time $\mathrm{t}$

The values of Organic Matter Digestibility (OMD) and Metabolisable Energy (ME) of the samples were calculated by the equation of Menke and Steingass (1988):

$\mathrm{OMD}(\mathrm{g} / 100 \mathrm{~g} \mathrm{DM})=14.88+0.889 \times \mathrm{GP}+0.45 \times \mathrm{CP}+0.0651 \times \mathrm{XA}$

$$
\mathrm{ME}\left(\mathrm{MJ} \mathrm{kg}^{-1}\right)=2.20+0.136 \mathrm{GP}+0.057 \mathrm{CP}+0.0029 \mathrm{CP}^{2}
$$

Where:

$\mathrm{GP}=$ Total $24 \mathrm{~h}$ net gas production $(\mathrm{mL} / 200 \mathrm{mg})$

$\mathrm{CP}=$ Crude Protein $(\%)$

$\mathrm{X}=$ Ash content $(\%)$

Data were statistically analyzed using GLM of SAS.

\section{RESULTS AND DISCUSSION}

Chemical composition: The chemical composition of the untreated and the chemically treated of sesame stover are shown in Table 1. Chemical composition of the samples was effected by the chemical treatment. Neutral Detergent Fiber $(\mathrm{NDF})$ was significantly $(\mathrm{p}<0.05)$ decreased by sulphuric acid treatment. The main difference between untreated and treated sesame stover was observed in crude protein content as a result of the addition of urea. Urea caused a significant $(\mathrm{p}<0.001)$ increase in CP content of SS than the other treatments. Vadiveloo (2003) showed that the treatment Malaysian rice straw with $4 \%$ urea increased CP content from $(6.0 \%)$ for the untreated to $(9.3 \%)$ for treated rice straw. This was agreed with the finding of Al-Shami and Al-Sultan (2006) who reported crude protein content was increased to $8 \%$ for urea treated straw. 
Table 1: Chemical composition of sesame stover as untreated or treated treated with $\mathrm{NaOH}$, urea or sulphuric acid

\begin{tabular}{|c|c|c|c|c|c|c|c|}
\hline \multirow[b]{2}{*}{ Items } & \multicolumn{7}{|c|}{ Treatments* } \\
\hline & SS & SSA & SSU & SSN & SSUN & SEM & p-value \\
\hline NDF & $75.7^{\mathrm{a}}$ & $66.6^{\mathrm{d}}$ & $71.7^{\circ}$ & $69.9^{\circ}$ & $73.6^{\mathrm{ab}}$ & 0.85 & $<0.05$ \\
\hline $\mathrm{ADF}$ & 46.2 & 43.8 & 45.4 & 45.4 & 45.8 & 0.55 & NS \\
\hline $\mathrm{CP}$ & $6.7^{\mathrm{c}}$ & $6.7^{\mathrm{c}}$ & $11.8^{\mathrm{a}}$ & $6.3^{c}$ & $8.9^{b}$ & 0.13 & $<0.05$ \\
\hline $\mathrm{OM}$ & $96.4^{\mathrm{ab}}$ & $96.1^{\mathrm{b}}$ & $94.4^{d}$ & $96.5^{\mathrm{a}}$ & $95.7^{\mathrm{c}}$ & 0.09 & $<0.05$ \\
\hline
\end{tabular}

*SS: Sesame Stovet, SSA: Sesame Stover+Sulphuric Acid, SSU: Sesame Stover+Urea, SSN: Sesame Stover+NaOH, SSUN: Sesame Stover+NaOH+Urea; Means within a row with different superscripts differed at $p<0.05$

Table 2: In situ ruminal degradation of Dry Matter (DM) and Crude Protein (CP) of sesame stover as untreated or treated with NaOH, urea and sulphuric acid $(\mathrm{mean} \pm \mathrm{SE})$

\begin{tabular}{|c|c|c|c|c|c|c|c|}
\hline \multirow[b]{2}{*}{ Samples* } & \multicolumn{3}{|l|}{$\mathrm{DM}$} & \multicolumn{3}{|l|}{$\mathrm{CP}$} & \multirow[b]{2}{*}{$\mathrm{p}$-value } \\
\hline & $\mathrm{a}$ & $\mathrm{b}$ & c & $\mathrm{a}$ & $\mathrm{b}$ & c & \\
\hline $\mathrm{SS}$ & $0.22 \pm 0.015^{\mathrm{a}}$ & $0.36 \pm 0.01^{\mathrm{a}}$ & $0.07 \pm 0.010^{\mathrm{a}}$ & $0.30 \pm 0.028^{a}$ & $0.46 \pm 0.030^{\mathrm{a}}$ & $0.10 \pm 0.017^{\mathrm{a}}$ & $<0.05$ \\
\hline SSA & $0.28 \pm 0.01^{\mathrm{ab}}$ & $0.29 \pm 0.01^{b}$ & $0.06 \pm 0.008^{b}$ & $0.42 \pm 0.040^{\mathrm{b}}$ & $0.37 \pm 0.051^{b}$ & $0.04 \pm 0.017^{b c}$ & $<0.05$ \\
\hline SSU & $0.21 \pm 0.03^{\mathrm{ab}}$ & $0.35 \pm 0.03^{\mathrm{ac}}$ & $0.05 \pm 0.016^{b c}$ & $0.63 \pm 0.024^{c}$ & $0.21 \pm 0.032^{c}$ & $0.05 \pm 0.021^{\mathrm{b}}$ & $<0.05$ \\
\hline SSN & $0.30 \pm 0.019^{\circ}$ & $0.38 \pm 0.02^{\mathrm{d}}$ & $0.05 \pm 0.008^{c d}$ & $0.44 \pm 0.032^{b}$ & $0.35 \pm 0.052^{\mathrm{d}}$ & $0.038 \pm 0.014^{\mathrm{d}}$ & $<0.05$ \\
\hline SSUN & $0.23 \pm 0.024^{b}$ & $0.36 \pm 0.02^{\mathrm{ac}}$ & $0.05 \pm 0.011^{\mathrm{d}}$ & $0.53 \pm 0.026^{\mathrm{d}}$ & $0.25 \pm 0.031^{\mathrm{e}}$ & $0.049 \pm 0.017^{c}$ & $<0.05$ \\
\hline
\end{tabular}

*SS (Sesame Stovet), SSA (Sesame Stover+sulphuric acid), SSU (Sesame Stover+Urea), SSN (Sesame Stover+NaOH), SSUN (Sesame Stover+NaOH+Urea); Means within a row with different superscripts differed at $\mathrm{p}<0.05$

Table 3: Gas production parameters of sesame stover treated with $\mathrm{NaOH}$, urea or sulphuric acid (mean $\pm \mathrm{SE}$ ) Treatment*

\begin{tabular}{|c|c|c|c|c|c|c|}
\hline \multirow[b]{2}{*}{ Parameters } & & & & & & \multirow[b]{2}{*}{$\mathrm{p}$-value } \\
\hline & SS & SSA & $\mathrm{SSU}$ & $\mathrm{SSN}$ & SSUN & \\
\hline $\mathrm{b}(\mathrm{mL} / 0.2 \mathrm{~g})$ & $59 \pm 2.3^{\mathrm{a}}$ & $51 \pm 2.5^{b}$ & $60 \pm 2.8^{\mathrm{ac}}$ & $72 \pm 2.9^{d}$ & $62 \pm 2.5^{\mathrm{c}}$ & $<0.05$ \\
\hline$c(/ h)$ & $0.04 \pm 0.004^{\mathrm{a}}$ & $0.04 \pm 0.006^{\mathrm{a}}$ & $0.03 \pm 0.003^{b}$ & $0.02 \pm 0.002^{c}$ & $0.03 \pm 0.003^{b}$ & $<0.05$ \\
\hline $\mathrm{ME}\left(\mathrm{MJ} \mathrm{kg}^{-1}\right)$ & 7.8 & 7.23 & 8.02 & 7.98 & 7.78 & NS \\
\hline OMD $(\mathrm{g} / 100 \mathrm{~g} \mathrm{DM})$ & 54.48 & 50.6 & 56.78 & 56.02 & 52.58 & NS \\
\hline
\end{tabular}

*SS: Sesame Stovet, SSA: Sesame Stover+Sulphuric Acid, SSU: Sesame Stover+Urea, SSN: Sesame Stover+NaOH, SSUN: Sesame Stover+NaOH+Urea; Means within a row with different superscripts differed at $p<0.05$

In situ degradation: The values of in situ ruminal degradation coefficients of DM and CP of the experimental samples are shown in Table 2. Results showed that the chemical treatments applied in the present study did alter the degradation coefficients of SS. Quickly and slowly degradable fractions for DM and CP were significantly affected by the treatments $(p<0.05)$. DM degradation rates (both $\mathrm{a}$ and $\mathrm{b}$ fractions) of SSUN was significantly $(p<0.05)$ higher than those of the other treatments.

These results confirmed the finding of Chaudhry (1998) who observed that the digestibility of DM of wheat straw was increased by treatment with $\mathrm{NaOH}$. Chaudhry (2000) described that the treatment with $\mathrm{NaOH}+\mathrm{Ca}(\mathrm{OH})_{2}$ caused the greatest disappearance of DM, OM and NDF. In addition, he showed that the quickly degradable fractions of $\mathrm{DM}, \mathrm{OM}$ and $\mathrm{NDF}$ were greatest for $\mathrm{NaOH}+\mathrm{Ca}(\mathrm{OH})_{2}$ treated straw compared with the untreated.

It may be due to the greater effect of $\mathrm{NaOH}$ on the lignin molecule to release phenolics to inhibit rumen microbes and consequently rumen degradation of straw (Marvin et al., 1996). Results of the present study demonstrated that the slowly degradable fraction of DM was the greatest for the sample treated by sulphuric acid compared with those of the untreated or the other samples. The degradation constant rate of the treated samples was significantly higher than that of the untreated sample $(p<0.05)$. In the present study the quickly degradable fraction (a) of CP was significantly $(p<0.05)$ increased when urea was applied. Urea affects the cuticle wax to enhance the digestibility of parenchyma tissue through swelling of the wall of parenchyma cells and cracking of the wall of vascular tubes. Therefore, urea causes both physical and chemical changes in fibrous feed tissues and cell walls (Shen et al., 1999) facilitating degradation by rumen bacteria and an increase in degradability especially of the leaf fraction (Vadiveloo, 2000). Prasad et al. (1998) observed that DM intake was significantly higher in urea treated rice straw than on untreated straw which might be due to improved palatability.

In vitro gas production: In vitro gas production parameters ( $b$ and $c$ ), $O M D$ and $M E$ values of the experimental samples are shown in Table 3 . The $b$ fraction of gas production was significantly $(\mathrm{p}<0.05)$ higher when seasame stover was treated with $\mathrm{NaOH}$ than those of the others. $\mathrm{NaOH}$ caused a significant decrease in c fraction of SS compared with the other treatments $(\mathrm{p}<0.05)$. While there was an increase in $\mathrm{b}$ fraction of gas production of SS when was treated by $\mathrm{NaOH}(\mathrm{p}<0.05)$. The present effect of 
$\mathrm{NaOH}$ on gas production parameters of sesame stover confirmed the results of Liu et al. (2002) who found that $\mathrm{NaOH}$ improved gas production of rice straw.

Chaji et al. (2010) observed that processing sugarcane pith with high steam $+\mathrm{NaOH}$ caused an increase in gas produced parameters ( $\mathrm{b}$ and $\mathrm{c}$ ). They described that treating sugarcane pith with $\mathrm{NaOH}$ had the highest cell wall degradability. Treatment of wheat straw with $\mathrm{NaOH}$ may have removed some chemical linkages within hemicelluloses and thus enhanced their solubility in detergent solutions (Chaudhry, 1998). The reduction in $\mathrm{NDF}$ of wheat straw by $\mathrm{NaOH}$ treatment was mainly due to decrease hemicelluloses content (Haddad et al., 1995).

It was reported that an alkali solution solubilizes the inhibitory phenolic compounds and hemicelluloses (Chen et al., 2007). Gould (1984) proposed that alkali react with lignocelluloses to yield partially delignified products that are highly susceptible to enzymatic and microbial attach, about $20 \%$ loss in the initial DM following sodium hydroxide treatment. Kamalak et al. (2005) observed that gas produced at all incubation times of corn silage was significantly higher than those of wheat straw and barley straw. Therefore, the estimated parameters (c and b) of corn silage were significantly higher than the others. They also expressed that the cell wall content (NDF and ADF) had negatively correlated with gas production at all incubation times.

The negative correlation between gas production and the cell wall content might be a result of the reduction of microbial activity from increasingly adverse environmental conditions as the incubation time progresses. Under present experimental condition, both Metabolizable Energy (ME) and Organic Matter Digestibility (OMD) was not affected by the chemical treatments applied (Table 3 ). These results did not confirm the finding of Chaji et al. (2010). They showed that high steam and $\mathrm{NaOH}$ caused to increase in vitro cell wall degradation, OMD and ME of sugarcane pith.

\section{CONCLUSION}

In conclusion, present results indicate that chemical treatment such as sodium hydroxide is highly effective chemical treatment for improving degradability of the sesame stover. In addition, sodium hydroxide cause to enhance the fermentability of the fibrous feed evaluated. On the other hand, urea applied at the present rate to treat the seame stover creat a suitable condition to improve the ruminal degradation of CP. Therefore, it has been suggested that sodium hydroxide and urea might use as appropriate agents for improving digestion and nutrition value of sesame stover.

\section{REFERENCES}

Al-Shami and S.A. Al-Sultan, 2006. Effect of treating wheat straw with urea on its crude protein content. J. Anim. Vet. Adv., 5: 440-442.

Celik, K., I.E. Ersoy and F. Savran, 2003. Feeding of urea treated wheat straw in saanen goat male kids. Pak. J. Nutr., 2: 258-261.

Chaji, M., T. Mohammadabadi, M. Mamouei and S. Tabatabaei, 2010. The effect of processing with high steam and sodium hydroxide on nutritive value of sugarcane pith by in vitro gas production. J. Anim. Vent. Adv., 9: 1015-1018.

Chaudhry, A.S., 1998. Nutrient digestion and rumen fermentation in sheep of wheat straw treated with calcium oxide, sodium hydroxide and alkaline hydrogen peroxide. Anim. Feed Sci. Technol., 74: $315-328$.

Chaudhry, A.S., 2000. Rumen degradation in sacco in sheep of straw treated with calcium oxide, sodium hydroxide and sodium hydroxide plus hydrogen peroxide. Anim. Feed Sci. Technol., 83: 313-323.

Chen, X.L., J.K. Wang, Y.M. Wu and J.X. Liu, 2007. Effects of chemical treatments of rice straw on rumen fermementation characteristics, fibroltic enzyme activities and populations of liquid and solid associated ruminal microbes in vitro. Anim. Feed Sci. Technol., 141: 1-14.

Gould, J.M., 1984. Alkaline peroxide delignification of agricultural residues to enhance enzymatic saccarification. Biotechnol. Bioeng., 26: 46-52.

Haddad, S.G., R.J. Grant and T.J. Klopfenstein, 1995. Digestibility of alkali-treated wheat straw measured in vitro or in vivo using Holstein heifers. J. Anim. Sci., 73: 3258-3265.

Horn, H.W., J. Zorrila-Rios and D.E. Akin, 1989. Influence of stage of forage maturity and ammoniation of wheat straw on rumina degradation of wheat forage tissues. J. Anim. Sci. Technol., 24: 201-218.

Kamalak, A., O. Canbolat, Y. Gukbuz and O. Ozay, 2005. Comparison of in vitro gas production technique with in situ nylon bag technique to estimate dry matter degradation. Czech. J. Anim. Sci., 50: $60-67$.

Liu, J.X., A. Susenbeth and K.H. Sudekum, 2002. In vitro gas production measurements to evaluate interaction between untreated and chemically treated rice straws, grass hay and mulberry leaves. J. Anim. Sci., 80: $517-524$. 
Marvin, H.J.P., C.F. Krechting, E.N. van Loo, C.H.A. Snijders, A. Lommen and O. Dolstra, 1996. Relationship between phenolic acids formed during rumen degradation of maize of samples and in vitro digestibility. J. Sci. Food Agric., 71: 111-118.

Mehrez, A.Z. and E.R. Orskov, 1977. A study of artificial fiber bag technique for determinin the digestibility of feeds intherumen. J. Agric. Sci., 88: 645-650.

Menke, K.H. and H. Steingass, 1988. Estimation of the energetic feed value obtained from chemical analysis and gas production using rumen fluid. Anim. Res. Dev., 28: 7-55.

Mesgaran, M.D., M. Malekkhahi, H.J. Azizabadi, A.R.H. Mousavi, A. Tahmasbi, A. Vakili and H.N. Moghaddam, 2009. In vitro gas production parameters of Sesame (Sesame indicum) stover treated with Sodium Hydroxide and urea. Proceedings of the Animal Nutrition Association World Coference, Feb. 14-17, New Delhi, India, pp: $1-1$.

Orskov, E.R., F.D.D. Hovell and F. Mould, 1980. The use of the nylon bag technique for the evaluation of feed stuffs. Trop. Anim. Prod., 5: 195-213.

Prasad, R.D.D., M.R. Reddy and G.V.N. Reddy, 1998. Effect of feeding baled and staked urea treated rice straw on the performance of crossbred cows. Anim. Feed Sci. Technol., 73: 347-352.
Ribeiro, J.M.C.R., 1991. Treatment straw. Options Mediterraneennes-Serie Seminaires, No. 16, pp: 55-60. http://ressources.ciheam.org/om/pdf/a16/ 91605045.pdf.

Shen, H.S., F. Sundstol, E.R. Eng and L.O. Eik, 1999. Studies on untreated and urea-treated rice straw from three cultivation seasons. 3: Histological investigations by light and scanning electron microscopy. Anim. Feed Sci. Technol., 80: 151-159.

Silva, A.T. and E.R. Qrskov, 1988. Fibre degradation in the rumens of animals receiving hay, untreated or ammonia-treated straw. Anim. Feed Sci. Technol., 19: $277-287$.

Vadiveloo, J., 2003. The effect of agronomic improvement and urea treatment on the nutritional value of Malaysian rice straw varieties. Anim. Feed Sci. Technol., 108: 133-146.

Vadiveloo, J., 2000. Nutritional properties of the leaf and stem of rice straw. Anim. Feed Sci. Technol, 83: $57-65$.

Van Soest, P.J., J.B. Robertson and B.A. Lewis, 1991. Methods for dietary neutral detergent fiber and non starch polysaccharides in relation to animal nutrition. J. Dairy Sci., 74: 3583-3597.

Weixian, Z., Y. Jingka, T. Hongli and S. Tamminga, 1995. Influence of microbial fermented straw on intake and growth rate in young beef cattle. Livest. Res. Rural Dev., Vol. 7. 